\title{
Xg Blood Group Frequencies in Some Further Populations
}

\author{
WILLIAM J. DEWEY and JOSEPH D. MANN \\ with the assistance of C. E. JACKSON*, WILLIAM BOUMAN $†$, \\ H. SAMUEL NOORDHOFF + , T. C. WU + , and HARVEY DOORENBOS§ \\ From the Heritable Metabolic Diseases Section, Illinois Department of Public Health, and \\ Butterworth Hospital, Grand Rapids, Michigan, U.S.A.
}

Gene frequency estimates for the two alleles in the $\mathrm{Xg}$ blood group system in several populations have been published. Table I summarizes the information available to date. $\mathrm{Xg}$ and other blood group frequencies in further populations are reported here.

Table II summarizes the data on four middle western groups. The Amish population lives in an area centered near Wells County, Indiana, and is

Received August 5, 1966.

* Caylor-Nickel Clinic and Foundation, Bluffton, Indiana.

† University of Michigan, Ann Arbor, Michigan.

$\ddagger$ Mackay Memorial Hospital, Taipei, Taiwan.

$\S$ American Mission, Box I, Bahrain, Arabian Gulf. principally of Swiss extraction. The effective population size is not known, but the level of inbreeding is extremely high. The population appears to deviate from random mating in the small samples so far studied, but the breeding structure is such that we presume this finding to be an artefact.

The Grand Rapids and Bluffton Caucasian populations are each derived from obstetrical series in private general hospitals in their respective locations, and consist of married couples ascertained through confinement of the wife for delivery. The Negro population is comprised of the small number of Negro couples from the two hospital series, pooled, plus some unrelated American Negroes living in Grand Rapids at the time of testing, Most of the families in the Grand Rapids, Bluffton.

TABLE I

Xg FREQUENCIES PREVIOUSLY REPORTED

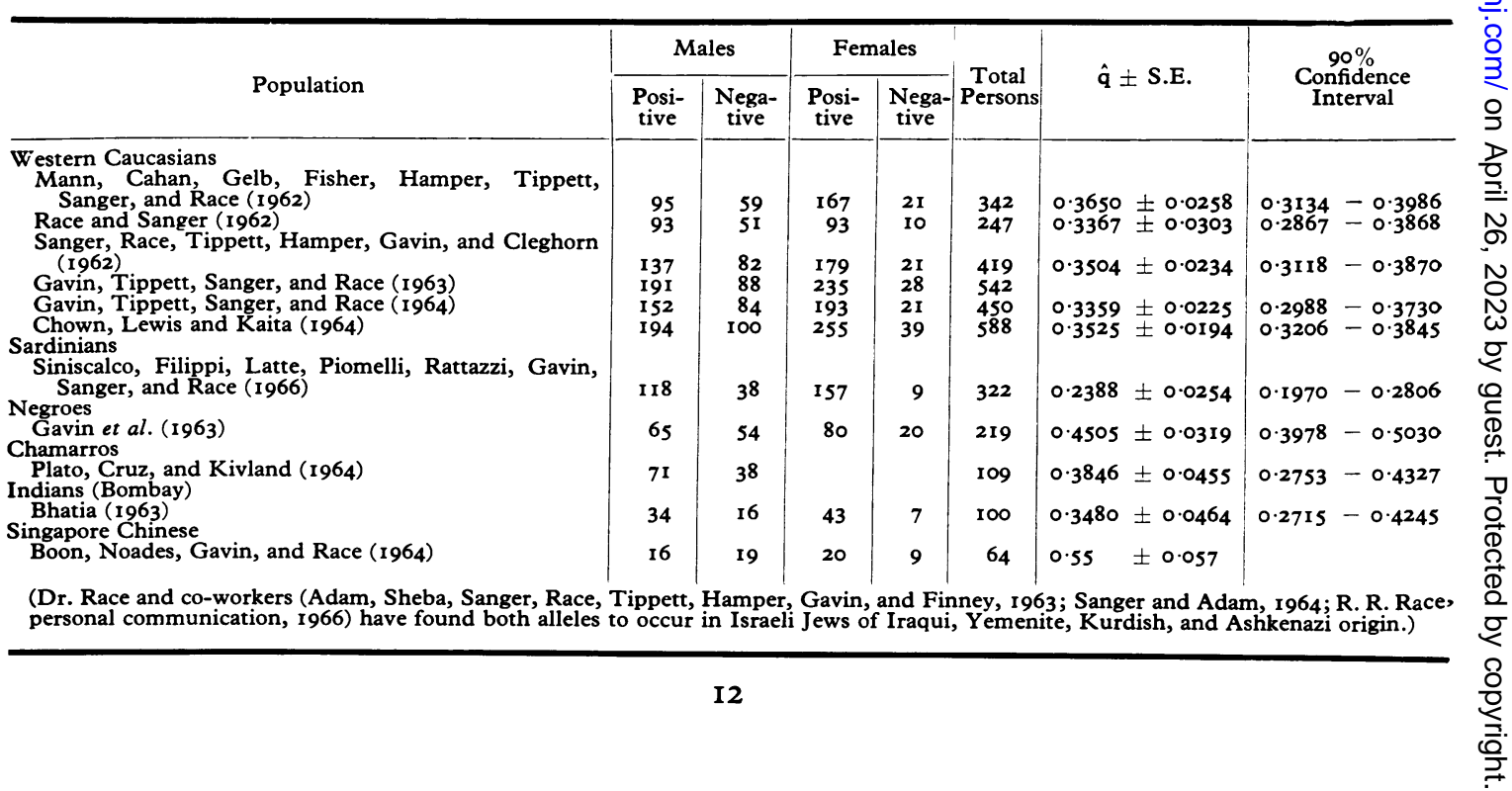


TABLE II

Xg FREQUENCIES IN FOUR MIDWESTERN UNITED STATES GROUPS

\begin{tabular}{|c|c|c|c|c|c|c|c|}
\hline \multirow{2}{*}{ Population } & \multicolumn{2}{|c|}{ Males } & \multicolumn{2}{|c|}{ Females } & \multirow{2}{*}{$\begin{array}{c}\text { Total } \\
\text { Persons }\end{array}$} & \multirow{2}{*}{$\hat{\mathbf{q}} \pm \mathbf{S} . \mathbf{E}}$. & \multirow{2}{*}{$\begin{array}{l}90 \% \text { Confidence } \\
\text { Interval }\end{array}$} \\
\hline & Positive & Negative & Positive & Negative & & & \\
\hline $\begin{array}{l}\text { Amish } \\
\text { Caucasians }\end{array}$ & 28 & 13 & 28 & 13 & 82 & $0.4607 \pm 0.0483$ & $0.3810-0.5403$ \\
\hline $\begin{array}{l}\text { Grand Rapids } \\
\text { Bluffton }\end{array}$ & $\begin{array}{r}372 \\
97\end{array}$ & $\begin{array}{r}171 \\
51\end{array}$ & $\begin{array}{l}474 \\
131\end{array}$ & $\begin{array}{l}69 \\
17\end{array}$ & $\begin{array}{r}1086 \\
296\end{array}$ & $\begin{array}{l}0.3361 \pm 0.0141 \\
0.3417 \pm 0.0275\end{array}$ & $\begin{array}{l}0.3128-0.3594 \\
0.2964-0.3870\end{array}$ \\
\hline Pooled & 469 & 222 & 605 & 86 & 1382 & $0.3373 \pm 0.0126$ & $0.3165-0.3581$ \\
\hline Negroes & I I & 8 & 19 & 9 & 47 & $0.5200 \pm 0.0642$ & $0.4142-0.6258$ \\
\hline
\end{tabular}

and Negro series are the same families as those in which we have observed an apparent interaction between the $\mathrm{Xg}$ blood group system and the sex ratio (Dewey, Mann, Wilson, and Jackson, 1965).

We have reported briefly on the $\mathrm{Xg}$ frequencies found among a sample of American Indians (Bouman, Mann, and Dewey, 1966). Our work with this source is now completed, and the entire body of these data are represented in Table III. All the tribes represented appear to have low frequencies of the negative allele; in view of the small numbers and well-known difficulty of sampling American Indians, it is difficult to make any inferences from these isolated observations.

We have obtained bloods from a number of populations on Taiwan. These data are summarized in Tables IV and V.
The Mainland Chinese of Table IV are postWorld War II emigrants to the island from Mainland China. They show a lower gene frequency than the Singapore Chinese. The Taiwanese Chinese were on the island before the latest influx, being descendants of eighteenth-century emigrants from Fuchien province on the South eastern coast of China. Their Xg frequency is somewhat higher. The Hakka represent a still earlier invasion of the island, originating in Kwangtung province on the southern coast in the sixteenth and seventeenth centuries.

The mountain tribes are the aboriginal inhabitants of Taiwan. The Tayal tribe, which we have studied most extensively, live in extremely rugged mountains in the northern interior, south of Taipei. The other tribes which we have sampled largely

TABLE III

Xg FREQUENCIES IN AMERICAN INDIANS

\begin{tabular}{|c|c|c|c|c|c|c|c|}
\hline \multirow{2}{*}{ Tribe } & \multicolumn{2}{|c|}{ Males } & \multicolumn{2}{|c|}{ Females } & \multirow{2}{*}{$\begin{array}{c}\text { Total } \\
\text { Persons }\end{array}$} & \multirow{2}{*}{$\hat{\mathbf{q}} \pm$ S.E. } & \multirow{2}{*}{$\begin{array}{c}90 \% \text { Confidence } \\
\text { Interval }\end{array}$} \\
\hline & Positive & Negative & Positive & Negative & & & \\
\hline $\begin{array}{l}\text { Navajo } \\
\text { Cheyenne } \\
\text { Zuni } \\
\text { Miscellaneous (I } 4 \text { other } \\
\text { tribes and hybrids represented) }\end{array}$ & $\begin{array}{r}107 \\
5 \\
39\end{array}$ & $\begin{array}{r}27 \\
0 \\
4\end{array}$ & $\begin{array}{r}163 \\
23 \\
14\end{array}$ & $\begin{array}{r}\mathbf{I} \mathbf{I} \\
\mathbf{I} \\
0\end{array}$ & $\begin{array}{r}308 \\
29 \\
57\end{array}$ & $\begin{array}{l}0.2266 \pm 0.0252 \\
0.1527 \pm 0.0999 \\
0.0884 \pm 0.0420 \\
0.21 \pm 0.08\end{array}$ & $\begin{array}{l}0.1850-0.2682 \\
0.000-0.3176 \\
0.0190-0.1577\end{array}$ \\
\hline
\end{tabular}

TABLE IV

Xg FREQUENCIES IN POPULATIONS ON TAIWAN

\begin{tabular}{|c|c|c|c|c|c|c|c|}
\hline \multirow{2}{*}{ Population } & \multicolumn{2}{|c|}{ Males } & \multicolumn{2}{|c|}{ Females } & \multirow{2}{*}{$\begin{array}{c}\text { Total } \\
\text { Persons }\end{array}$} & \multirow{2}{*}{$\hat{\mathbf{q}} \pm$ S.E. } & \multirow{2}{*}{$\begin{array}{l}90 \% \text { Confidence } \\
\text { Interval }\end{array}$} \\
\hline & Positive & Negative & Positive & Negative & & & \\
\hline $\begin{array}{l}\text { Mainland Chinese } \\
\text { Taiwanese Chinese } \\
\text { Hakka } \\
\text { Mountain tribes: }\end{array}$ & $\begin{array}{l}97 \\
33 \\
40\end{array}$ & $\begin{array}{l}64 \\
33 \\
32\end{array}$ & $\begin{array}{r}8 \\
88 \\
48\end{array}$ & $\begin{array}{r}2 \\
24 \\
16\end{array}$ & $\begin{array}{l}171 \\
178 \\
136\end{array}$ & $\begin{array}{l}0.4010 \pm 0.0379 \\
0.4747 \pm 0.0558 \\
0.4744 \pm 0.0397\end{array}$ & $\begin{array}{l}0.3387-0.4633 \\
0.3829=0.5664 \\
0.4090-0.5398\end{array}$ \\
\hline $\begin{array}{l}\text { Tayal } \\
\text { Non-Tayal }\end{array}$ & $\begin{array}{r}26 \\
0\end{array}$ & $\begin{array}{r}45 \\
I\end{array}$ & $\begin{array}{r}58 \\
8\end{array}$ & 35 & $\begin{array}{r}164 \\
\text { I } 5\end{array}$ & $\begin{array}{l}0.6203 \pm 0.0333 \\
0.67 \pm 0.10\end{array}$ & $0.5653-0.6752$ \\
\hline
\end{tabular}


TABLE V

ABO, MN, Fya, AND Rh(D) FREQUENCIES OF TAIWAN AND OTHER POPULATIONS

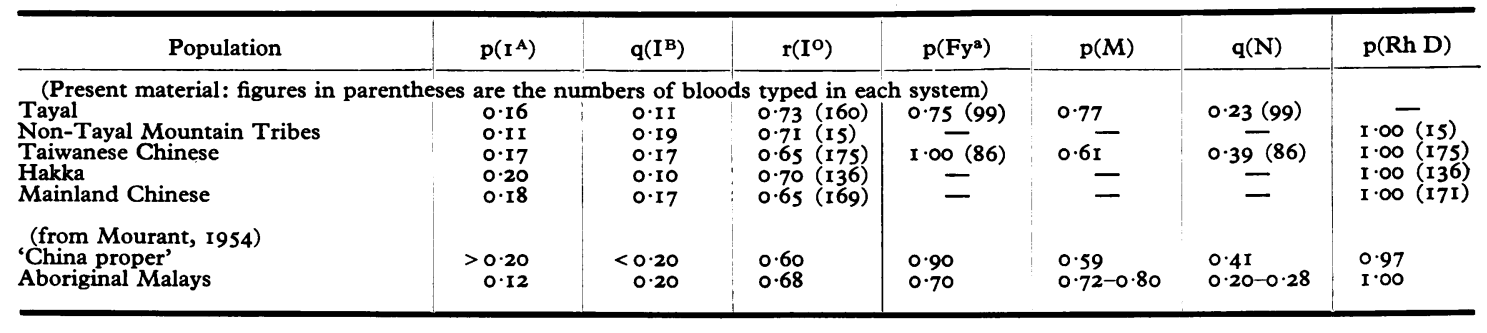

inhabit other mountainous areas. Local traditions have it that the Tayal and non-Tayal tribes have maintained rather strict isolation from each other for centuries, due to a mutual penchant for exoclinous headhunting. The Tayals were decimated by the Japanese armies early in World War II, in retaliation for indulging this habit on a Japanese garrison, producing a marked populationsize bottleneck and perhaps some shift in gene frequencies.

The ABO frequencies of these tribes were studied by Japanese workers before the war. Mourant (1954), citing Boyd (1939), says that the Tayals and some others lie well within the Chinese range of frequencies, while others more nearly resemble the Annamites or other Malaysian populations. This is not surprising, since both groups of mountain tribes are believed to derive from Malaysian emigration as early as 900 A.D. Physically, they are compact, muscular people, perhaps a little heavier, and more prognathic, than is typical of the other populations on Taiwan. Also, their skin colour is rather uniformly a dark, opaque, greyish-brown, quite distinct from the 'sun-tanned' hue of the Chinese.

Red cells of all males were tested for G6PD deficiency, and none were found to be deficient. There is endemic malaria on Taiwan, but it is not found in the high country inhabited by these tribes.

Table $\mathrm{V}$ gives our results for other blood group systems on Taiwan populations and the number of bloods upon which each estimate is based. Also given are Mourant's general figures for Chinese and Malaysians.

We have studied a small sample from one further population, Arabs from the Island of Bahrain in the Persian Gulf. The numbers observed were 20 males (I I positive and 9 negative) and 25 females (I4 positive and II negative). The estimate obtained from these data is $\hat{\mathrm{q}}=0.592 \pm 0.062$.

\section{Discussion}

The method of Haldane (I963) provides a test of consistency between the sexes of the estimate of the gene frequency. In every case except for one this test failed to show any disturbance. The one exception was the Tayal, in whom there was also a deficiency of $M N$ phenotypes, reaching a level of significance between 5 and $2 \%$. We presume that both these anomalies reflect the recent cataclysm in this population's history. Retyping failed to reveal any significant frequency of technical errors, and specimen deterioration seems unlikely, since the bloods from Taiwan generally made the 8000 mile journey to the laboratory within 24 hours. Analysis of the parents treated here as triplet observations, and of all Caucasians pooled, likewise revealed no deviations from expectation.

So far no population studied has lacked an appreciable frequency of either allele, the nearest to an exception being the Zuni Indians. In this respect $\mathrm{Xg}$ is reminiscent of the $\mathrm{MN}$ system. Professor Morton has presented evidence for heterosis maintaining the $\mathrm{MN}$ polymorphism, and both heterosis and incompatibility have been argued for as the explanation of the $\mathrm{ABO}$ polymorphism in man.

Further studies of $\mathrm{Xg}$ frequencies are being planned by ourselves and others.

\section{Summary}

The frequency of the blood types in the $\mathrm{Xg}$ system has now been studied in a number of populations. The published frequency data are summarized. Intergroup differences exist, but in all populations so far studied both alleles are found with relatively high frequencies.

Some of the work reported here was carried out while one of us (W.D.) was Research Associate in Maternal 
and Child Health, School of Public Health, The University of Michigan. This work was supported in part by USPHS-N.I.H. Grant GM 10474.

We wish to acknowledge the technical assistance of Raymond Marczynski, M.T. (ASCP), in the blood typing.

Dr. R. R. Race reviewed an earlier draft of this paper and very generously gave us much helpful criticism.

\section{REFERENCES}

Adam, A., Sheba, C., Sanger, R., Race, R. R., Tippett, P., Hamper, J., Gavin, J., and Finney, D. J. (1963). Data for x-mapping calculations, Israeli families tested for $\mathrm{Xg}, \mathrm{G}-6-\mathrm{PD}$, and for colour vision. Ann. hum. Genet., 26, 187.

Bhatia, H. M. (1963). Frequency of sex-linked blood group $\mathrm{Xg}^{\mathrm{a}}$ in Indians in Bombay. Ind. F. med. Sci., 17, 491 .

Boon, W. H., Noades, J., Gavin, J., and Race, R. R. (1964). Xg blood groups of Chinese. Nature (Lond.), $204,1002$.

Bouman, W., Mann, J. D., and Dewey, W. J. (1966). The Xg blood groups of American Indians. ibid., 209, $4 \mathrm{I}$ I.

Boyd, W. C. (1939). Blood groups. Tabul. biol. ('s-Grav.), 17, 113. Chown, B., Lewis, M., and Kaita, H. (1964). The Xg blood group system: data on 294 white families, mainly Canadian. Canad. 7. Genet. Cytol., 6, 43 I.

Dewey, W. J., Mann, J. D., Wilson, D. A., and Jackson, C. E. (1965). Apparent interaction between the $\mathrm{Xg}^{\mathrm{a}}$ blood group system and the sex ratio. Nature (Lond.), 206, 412.
Gavin, J., Tippett, P., Sanger, R., and Race, R. R. (1963). The $\mathrm{Xg}$ blood groups of Negroes. ibid., 200, 82.

- - - - - , and - (1964). The X-linked blood group Xg: II. Still more tests on unrelated people and on families. Vox Sang. (Basel), 9, 146 .

Haldane, J. B. S. (1963). Tests for sex-linked inheritance on population samples. Ann. hum. Genet., 27, 107.

Mann, J. D., Cahan, A., Gelb, A. G., Fisher, N., Hamper, J., Tippett, P., Sanger, R., and Race, R. R. (I962). A sex-linked blood group. Lancet, $\mathbf{1}, 8$.

Mourant, A. E. (1954). The Distribution of the Human Blood Groups. C. C. Thomas, Springfield, Illinois.

Plato, C. C., Cruz, M. T., and Kurland, L. T. (1964). Frequency of glucose-6-phosphate dehydrogenase deficiency, red-green colour blindness and $\mathrm{Xg}^{\mathrm{a}}$ blood group among Chamorros. Nature (Lond.), 202, 728.

Race, R. R., and Sanger, R. (1962). Blood Groups in Man, 4th ed. Blackwell Scientific Publications, Oxford.

Sanger, R., and Adam, A. (1964). Xg and g-6-PD in Israeli families: an addendum, Ann. hum. Genet., 27, 27 I.

Race, R. R., Tippett, P., Hamper, J., Gavin, J., and Cleghorn, T. E. (I962). The X-linked blood group system Xg: More tests on unrelated people and families.Vox Sang. (Basel), 7, 571 .

Siniscalco, M., Filippi, G., Latte, B., Piomelli, S., Rattazzi, M., Gavin, J., Sanger, R., and Race, R. R. (1966). Failure to detect linkage between $\mathrm{Xg}$ and other X-borne loci in Sardinians. Ann. hum. Genet., 29, 231. 